\title{
A New Cation-Exchange Method for Accurate Field Speciation of Hexavalent Chromium
}

Water-Resources Investigations Report 03-4018

Prepared in cooperation with the California Environmental Protection Agency, United States Marine Corps MCAGCC Twentynine Palms, and Edwards Air Force Base

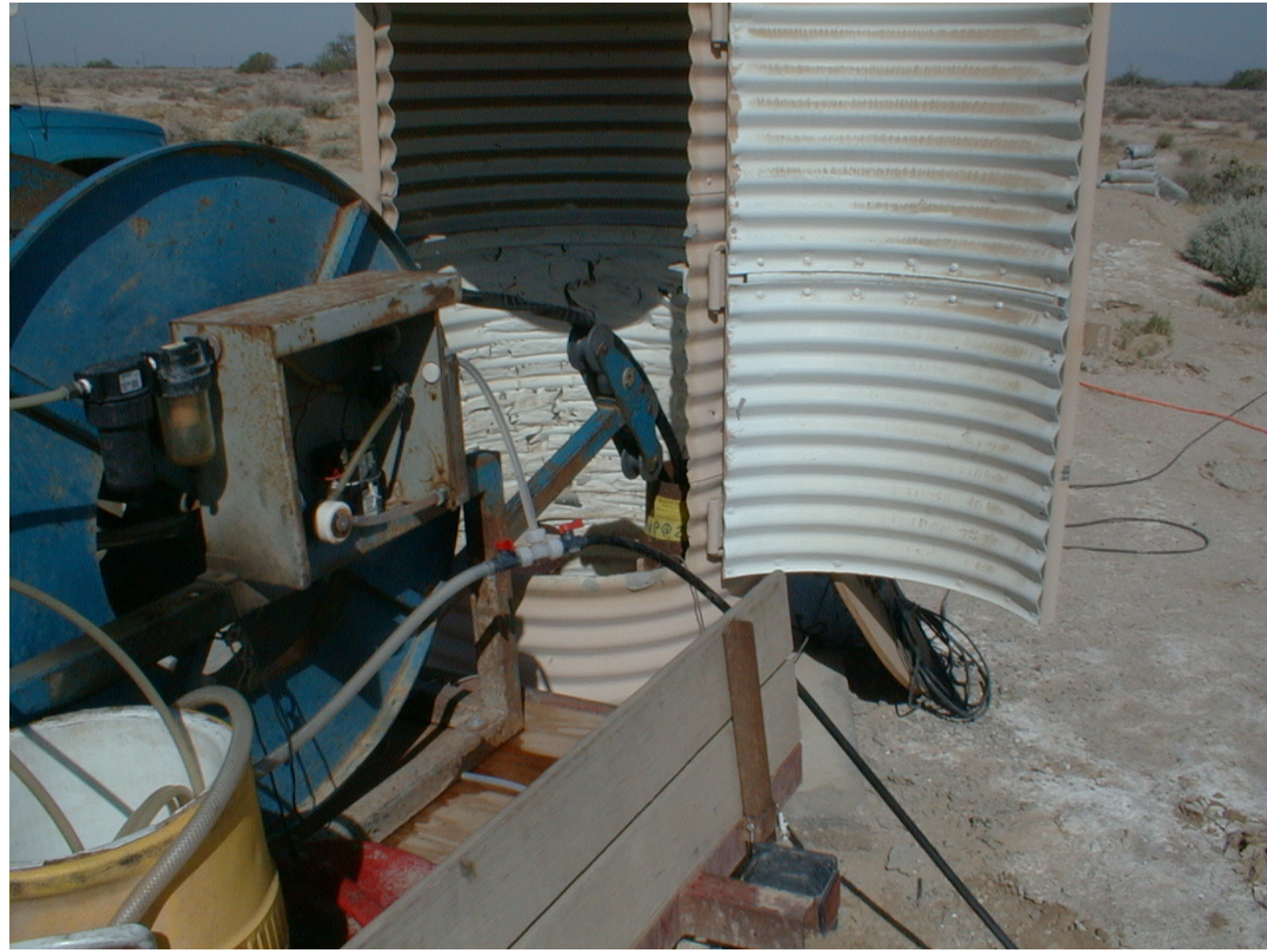

U.S. Department of the Interior U.S. Geological Survey 


\section{A New Cation-Exchange Method for Accurate Field Speciation of Hexavalent Chromium}

By James W. Ball and R. Blaine McCleskey

U.S. Geological Survey

Water-Resources Investigations Report 03-4018

Prepared in cooperation with the

California Environmental Protection Agency,

United States Marine Corps MCAGCC Twentynine Palms, and

Edwards Air Force Base

Front Cover Photography: Sampling a USGS monitoring well at 29 Palms Marine Base, May 2001

Boulder, Colorado

2003

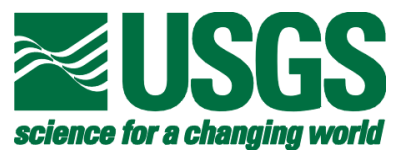




\section{U.S. DEPARTMENT OF THE INTERIOR \\ GALE A. NORTON, Secretary}

U.S. GEOLOGICAL SURVEY

Charles G. Groat Director

The use of firm, trade, and brand names in this report is for identification purposes only and does not constitute endorsement by the U.S. Geological Survey.

For additional information write to:

Chief, Branch of Regional Research

U.S. Geological Survey

Denver Federal Center

Box 25046, MS-418

Denver, Colorado 80225
Copies of this report can be purchased from:

U.S. Geological Survey

Branch of Information Services

Denver Federal Center,

Box 25286

Denver, Colorado 80225-0286 


\section{CONTENTS}

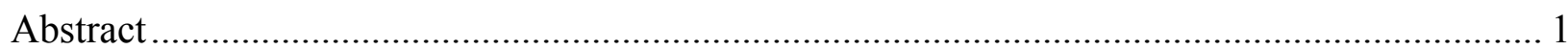

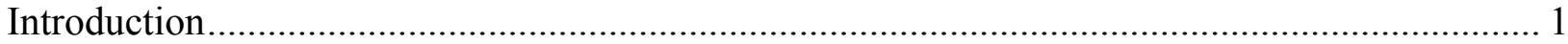

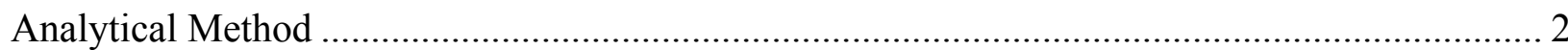

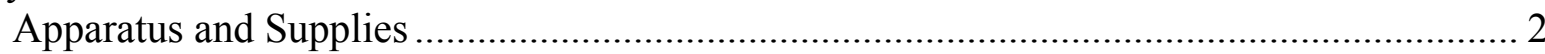

Field Procedure

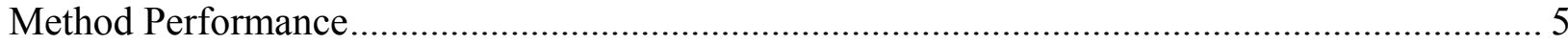

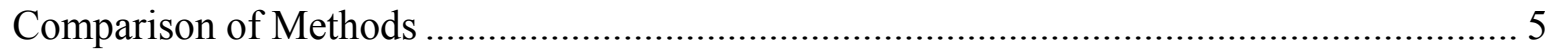

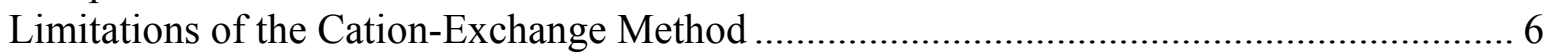

Accuracy of the Cation-Exchange Method: Standards and Spike Recoveries........................ 6

Comparison of Cation-Exchange Method Results with Results from Alternative

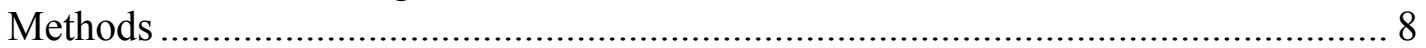

pH Dependence of the Cation-Exchange Separation ........................................................ 12

Effects of Potential Interfering Species on the Cation-Exchange and USEPA Methods..... 12

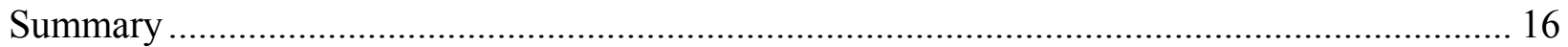

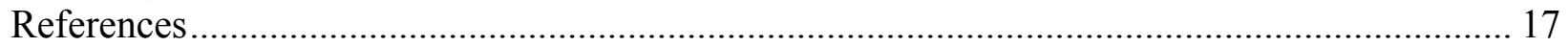

\section{FIGURES}

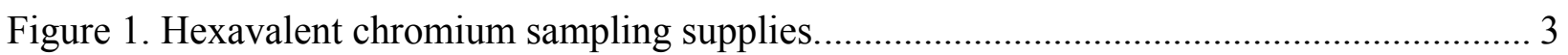

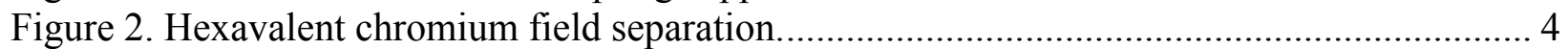

Figure 3. $\mathrm{Cr}(\mathrm{VI})$ determinations by the modified Hach DPC direct colorimetric method

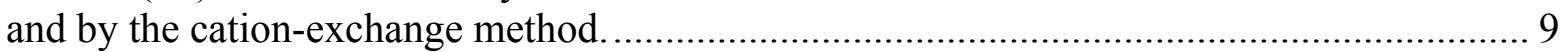

Figure 4. $\mathrm{Cr}(\mathrm{VI})$ determinations by USEPA method 218.6 and by the cation-exchange method. 10

Figure 5. $\mathrm{pH}$ dependence of $\mathrm{Cr}(\mathrm{VI})$ separation from synthetic solutions containing 20

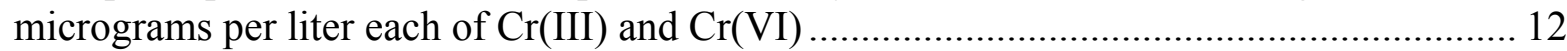

Figure 6. Recovery of 20 micrograms per liter $\mathrm{Cr}(\mathrm{VI})$ from solutions containing 0.1 to 10

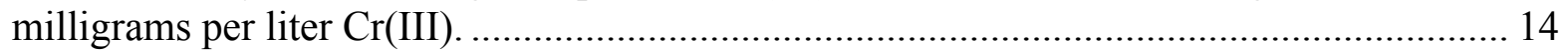

Figure 7. Recovery of 20 micrograms per liter $\mathrm{Cr}(\mathrm{VI})$ from solutions containing 20 micrograms per liter $\mathrm{Cr}(\mathrm{III})$ and 10 to 1000 milligrams per liter $\mathrm{Na}, \mathrm{Ca}$, or $\mathrm{Mg}$.................. 14

Figure 8. Recovery of 20 micrograms per liter $\mathrm{Cr}(\mathrm{VI})$ from solutions containing 20 micrograms per liter $\mathrm{Cr}(\mathrm{III})$ and 1 to 100 milligrams per liter $\mathrm{Ba}$...................................... 15

Figure 9. Recovery of 20 micrograms per liter $\mathrm{Cr}(\mathrm{VI})$ from solutions containing 20 micrograms per liter $\mathrm{Cr}(\mathrm{III})$ and 0.1 to 100 milligrams per liter $\mathrm{Fe}(\mathrm{II})$ or $\mathrm{Fe}(\mathrm{III}) \ldots \ldots \ldots \ldots \ldots \ldots . .15$

\section{TABLES}

Table 1. Recovery or retention from cation-exchanged $\mathrm{Cr}(\mathrm{III})$ and $\mathrm{Cr}(\mathrm{VI})$ standard solutions

Table 2. Results of analyses of four Cr-containing samples, each spiked with three

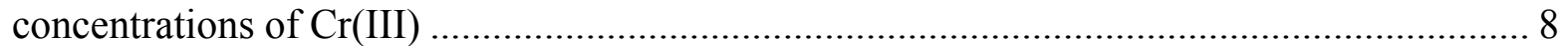

Table 3. Comparative $\mathrm{Cr}(\mathrm{VI})$ determinations in waters from around the world. ......................... 11 
Explanation of abbreviations

$\mathrm{Cr}$ (chromium)

DPC (diphenylcarbazide)

GFAAS (graphite furnace atomic absorption spectrometry)

IC (ion chromatography)

ICP-MS (inductively-coupled plasma-mass spectrometry)

$\mu \mathrm{g} / \mathrm{L}$ (micrograms per liter)

$\mu \mathrm{m}$ (micrometer)

$\mu \mathrm{S} / \mathrm{cm}$ (microSiemens per centimeter)

$\mathrm{mg} / \mathrm{L}$ (milligrams per liter)

$\mathrm{mL}$ (milliliter)

mm (millimeter)

USEPA (U.S. Environmental Protection Agency)

XANES (x-ray absorption near-edge structure spectrometry) 


\title{
A New Cation-Exchange Method for Accurate Field Speciation of Hexavalent Chromium
}

\author{
By James W. Ball and R. Blaine McCleskey
}

Abstract

A new cation-exchange method for field speciation of $\mathrm{Cr}(\mathrm{VI})$ has been developed to meet present stringent regulatory standards and to overcome the limitations of existing methods. The new method allows measurement of $\mathrm{Cr}(\mathrm{VI})$ concentrations as low as 0.05 micrograms per liter, storage of samples for at least several weeks prior to analysis, and use of readily available analytical instrumentation. The sensitivity, accuracy, and precision of the determination in waters over the $\mathrm{pH}$ range of 2 to 11 and Fe concentrations up to 1 milligram per liter are equal to or better than existing methods such as USEPA method 218.6. Time stability of preserved samples is a significant advantage over the 24-hour time constraint specified for USEPA method 218.6.

\section{INTRODUCTION}

Chromium (Cr) is usually present in surface and ground water in either the trivalent [Cr(III)] or the hexavalent $[\mathrm{Cr}(\mathrm{VI})]$ oxidation state. Since $\mathrm{Cr}$ (III) is considered an essential nutrient and $\mathrm{Cr}(\mathrm{VI})$ is considered a toxin and a carcinogen (Daugherty, 1992), it is important to distinguish between oxidation states of Cr. Chromium(VI) concentration limits for drinking water now being considered by the California Environmental Protection Agency present analysts with the need for quantitation limits in the sub- $\mu \mathrm{g} / \mathrm{L}$ range. Existing methods for accurately determining $\mathrm{Cr}(\mathrm{VI})$ in natural waters have one or more of the following weaknesses: (1) poor sensitivity, (2) timeinstability of the $\mathrm{Cr}$ redox species, or (3) necessity for expensive instrumentation that is not commonly available.

Concentrations of the redox states of chemical species dissolved in water are inherently unstable and subject to change by re-equilibration by reaction with other dissolved components, a coexisting solid phase, if present, or the atmosphere. Thus, concentrations of the respective redox states must be preserved in their initial state, determined at the time of collection, or separated from each other and preserved for later analysis. There are many methods available for determining redox species of $\mathrm{Cr}$, including flow injection chemiluminescence (Escobar and others, 1995), x-ray absorption near-edge structure spectrometry (XANES; Bajt and others, 1993), ion chromatography (IC; Arar and others, 1991; Arar and Pfaff, 1991), separation and preconcentration of the Cr(VI)diphenylcarbazide (DPC) complex by ion-exchange (Frenzel, 1998) or by using surfactant-coated alumina (Manzoori and others, 1996), and direct measurement of the Cr(VI)-DPC complex (Hach Company, 1992).

One of the most commonly used methods is U.S. Environmental Protection Agency (USEPA) method 218.6 (Arar and others, 1991; Arar and Pfaff, 1991). This method consists of injecting a sample into the sample loop of an ion chromatograph and using $\left(\mathrm{NH}_{4}\right)_{2} \mathrm{SO}_{4} / \mathrm{NH}_{4} \mathrm{OH}$ 
eluent solution to pump it through an anion-exchange column where the $\mathrm{Cr}(\mathrm{VI})$ is concentrated and separated from potential interferents. The Cr(VI) is then eluted from the resin, mixed with DPC color reagent, and passed through a flow-through absorbance detector. The absorbance of the solution is proportional to its $\mathrm{Cr}(\mathrm{VI})$ concentration. This method specifies that samples be preserved and adjusted to a $\mathrm{pH}$ of 9 to 10 with an $\left(\mathrm{NH}_{4}\right)_{2} \mathrm{SO}_{4} / \mathrm{NH}_{4} \mathrm{OH}$ buffer solution. More importantly, USEPA method 218.6 requires that samples be analyzed within 24 hours of collection to ensure that the distribution of dissolved $\mathrm{Cr}$ redox species remains unchanged, perhaps as a result of reequilibration of the sample with the gas phase.

Another popular method is direct colorimetric determination of $\mathrm{Cr}(\mathrm{VI})$ using DPC as the color reagent (Hach Company, 1992). This method is less sensitive than USEPA method 218.6, having a quantitation limit of $\geq 10 \mu \mathrm{g} / \mathrm{L}$ when used with a battery-powered field spectrophotometer and a 2.5-cm measuring cell, but is applicable as a field screening tool for detection of elevated $\mathrm{Cr}(\mathrm{VI})$ concentrations. In addition, colored solutions caused by the presence of dissolved organic compounds in natural waters, for example, constitute a potential source of positive interference. Other potential sources of interference include extreme sample $\mathrm{pH}$ or buffer capacity and elevated concentrations of other transition metals.

To address the need to overcome limitations of existing methods, the U.S. Geological Survey, in cooperation with the California Environmental Protection Agency, Department of Toxic Substances Control; the United States Marine Corps MCAGCC at Twentynine Palms, CA; and Edwards Air Force Base, developed and field tested a new cation-exchange method for fieldspeciation of $\mathrm{Cr}(\mathrm{VI})$.

This report describes the application of existing cation-exchange cartridge technology to the implementation of a new field method for collecting and preserving $\mathrm{Cr}(\mathrm{VI})$ dissolved in water. The method is simple, sensitive, accurate, and precise, the equipment needed is inexpensive and readily available, and analysis of samples for the $\mathrm{Cr}$ (VI) content can be achieved using commonly available instrumentation. The method is compared with the DPC direct colorimetric method and USEPA method 218.6.

The authors are pleased to acknowledge the cooperation and financial support of the California Environmental Protection Agency, Division of Toxic Substances Control, the U.S. Marine Corps MCAGCC at Twentynine Palms, California, and Edwards Air Force Base, California, and the Joshua Basin Water District. The authors also thank John Izbicki and Clinton Church of the USGS San Diego District Office for their collaboration and assistance. We also wish to thank John Izbicki and Randy Hanson of the USGS for colleague reviews of this manuscript.

\section{ANALYTICAL METHOD}

\section{Apparatus and Supplies}

Cation-exchange cartridges (IC-H, Alltech), disposable syringes, and suitable containers (centrifuge tubes) of size appropriate to process and hold sample volumes consistent with the laboratory analytical technique are required. Syringe filters $(25-\mathrm{mm}, 0.2-\mu \mathrm{m})$ are needed for 
unfiltered samples. Separated (speciated) samples are preserved with concentrated hydrochloric acid $(\mathrm{HCl})$ or nitric acid $\left(\mathrm{HNO}_{3}\right)$, American Chemical Society Reagent grade, for later measurement in the laboratory. The sampling supplies are shown in figure 1. An elemental analysis instrument capable of determining total $\mathrm{Cr}$ at concentrations in the range sought is needed for the measurement step. The new cation-exchange method was developed for use with the Zeeman-corrected graphite furnace atomic absorption spectrometry (GFAAS) analytical technique, with a detection limit of approximately $0.05 \mu \mathrm{g} / \mathrm{L}$ using end-capped transversely-heated graphite tubes. Consequently, sample volumes of $2 \mathrm{~mL}$ were collected using a 10-mL disposable syringe and stored in 2-mL centrifuge tubes. If a different analytical technique were used, such as inductively coupled plasmamass spectrometry (ICP-MS) with a conventional nebulizer, larger sample volumes would be required, necessitating use of larger syringes and storage containers, and possibly larger cationexchange cartridges.

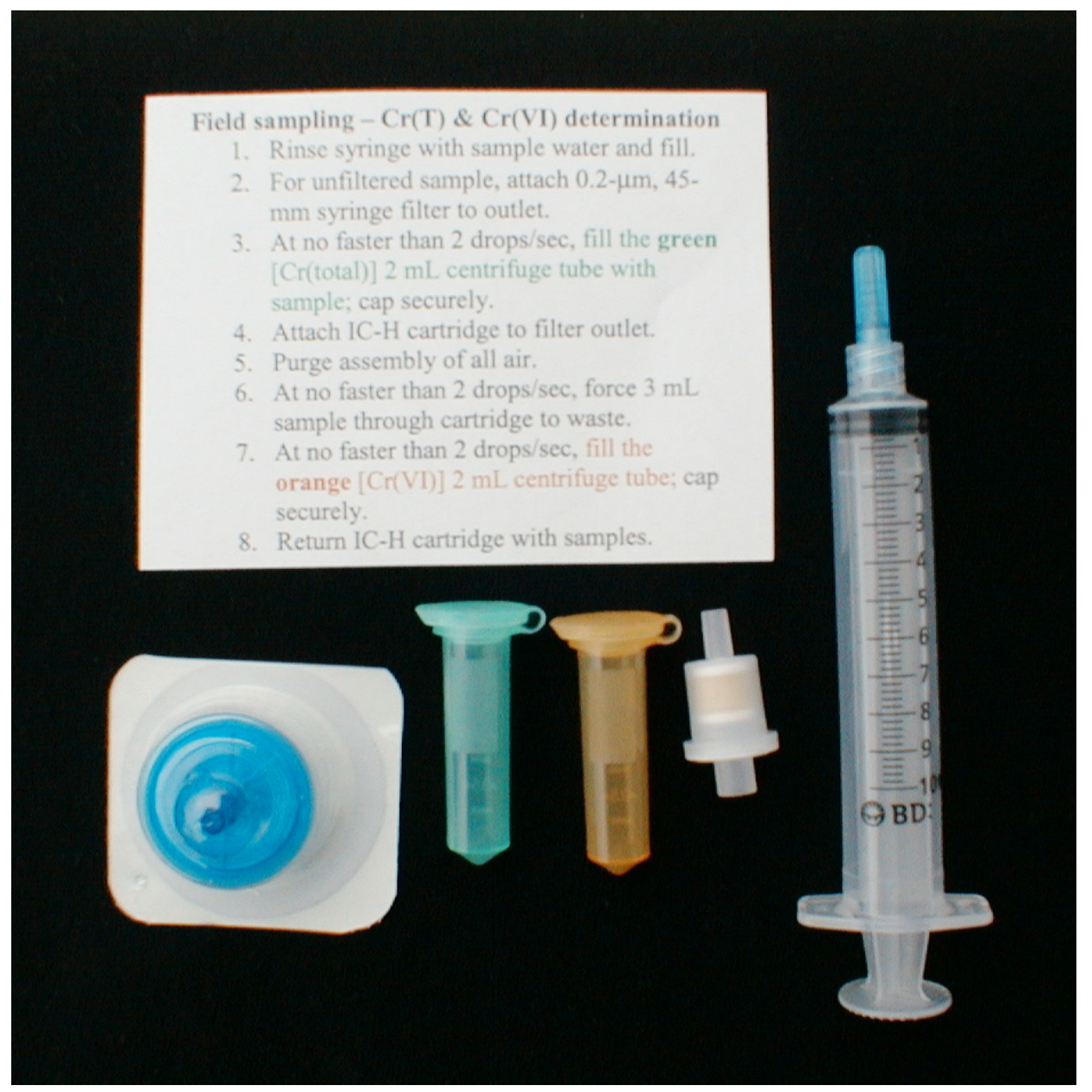

Figure 1. Hexavalent chromium sampling supplies. 


\section{Field Procedure}

Water samples collected in the field usually are near redox equilibrium with their immediate surroundings. This condition may change significantly after samples are collected. Examples of waters for which this may occur are deep ground water, geothermal water issuing from flowing hot springs, or interstitial lake bottom water. If the potential exists for re-equilibration of dissolved redox species as a result of interaction with post-collection conditions, such as exposure to atmospheric air, over a time frame shorter than that required for separating or preserving the $\mathrm{Cr}$ species, chemical changes in the species of interest should be tested for or prevented using appropriate measures.

A photograph of the separation procedure is shown in figure 2. Aspirate about $8 \mathrm{~mL}$ sample into a $10-\mathrm{mL}$ disposable plastic syringe. If the sample has not been filtered, use a syringe filter. Invert the assembly and purge of all air. Collect a sample for $\mathrm{Cr}$ (total) by filling the green 2-mL centrifuge tube. Attach an IC-H cartridge to the syringe/filter assembly. At no more than two drops per second, force about $3 \mathrm{~mL}$ sample through the assembly to waste. Again at no more than two drops per second, force about $2 \mathrm{~mL}$ sample through the assembly into the orange centrifuge tube. The sample issuing from the cation-exchange cartridge contains only $\mathrm{Cr}(\mathrm{VI})$, and because $\mathrm{Cr}$ (total) is determined in the laboratory measurement step, the oxidation state of $\mathrm{Cr}$ is no longer critical. Preserve the samples by acidifying to $\mathrm{pH}$ less than 2 with about $0.01 \mathrm{~mL} \mathrm{HCl}$ or $\mathrm{HNO}_{3}$. If necessary, the IC-H cartridge can be cleaned for reuse by passing $3 \mathrm{~mL} 2 \mathrm{M} \mathrm{HCl}$ followed by $5 \mathrm{~mL}$ doubledistilled or deionized water through it.

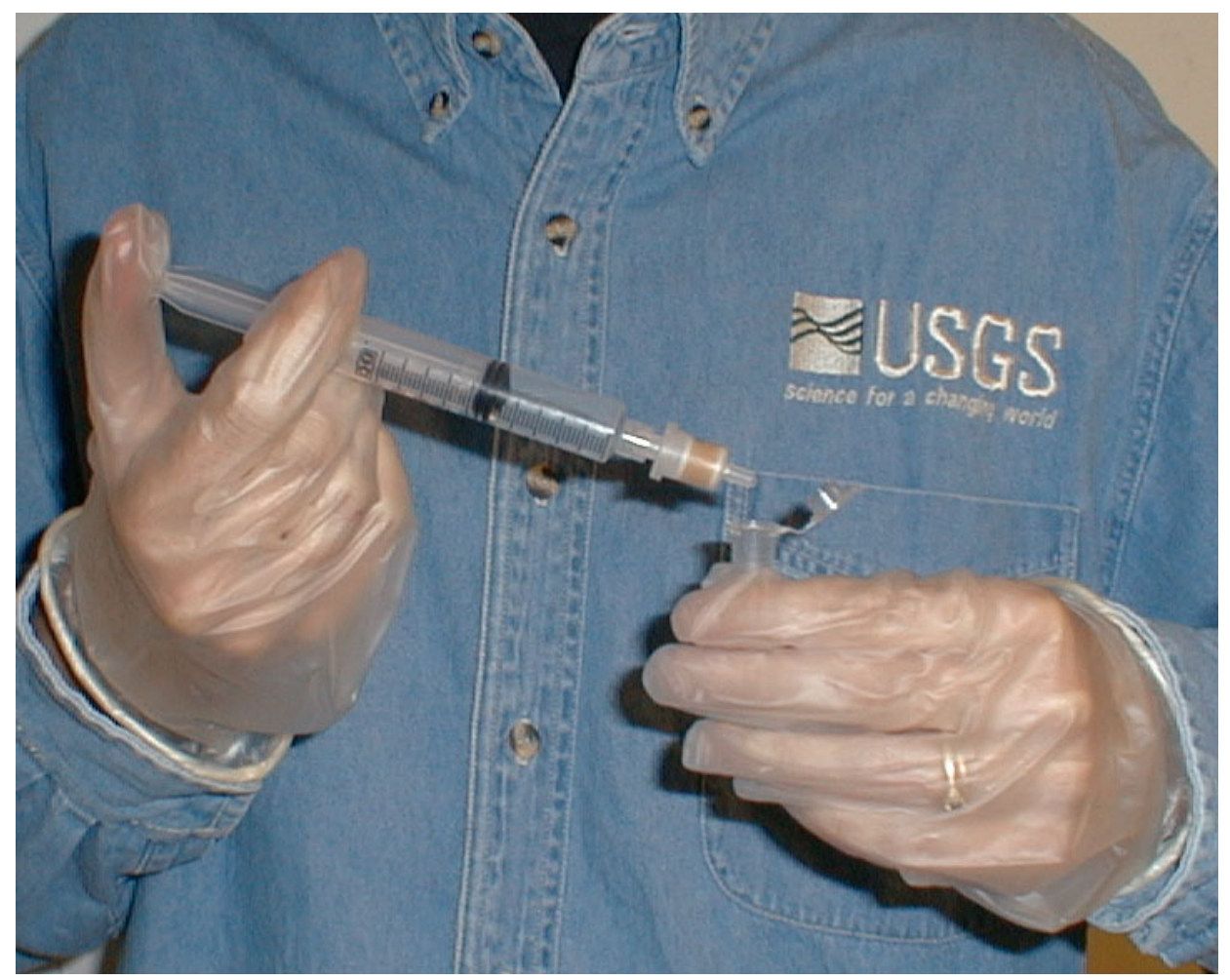

Figure 2. Hexavalent chromium field separation. 


\section{METHOD PERFORMANCE}

\section{Comparison of Methods}

Methods for determination of $\mathrm{Cr}$ require that the steps taken to collect and preserve samples are compatible with the analytical technique that will be used in the field or later in the laboratory. Three methods were compared for this study: DPC direct colorimetric method with analysis by spectrophotometry, USEPA method 218.6 with separation of the $\mathrm{Cr}(\mathrm{VI})$ species by ion chromatography and analysis by spectrophotometry, and the new cation-exchange method with analysis by Zeeman-corrected GFAAS. They differ in detection limits, potential for interferences, availability of analytical equipment, and time-stability of the preserved samples.

The field DPC direct colorimetric method makes use of a portable battery-powered spectrophotometer and a $2.5-\mathrm{cm}$ measuring cell. The cell is filled with sample, and then a packet of Hach ChromaVer3 powdered reagent is added. After color development, the absorbance of the solution is read and the $\mathrm{Cr}(\mathrm{VI})$ concentration is displayed in milligrams per liter. The two most important limitations of this method are its higher detection limit compared with other methods and the potential for interferences by unknown solution components.

The most commonly used method is USEPA method 218.6 (Arar and others, 1991). This method specifies that samples be preserved in the field and adjusted to a $\mathrm{pH}$ of 9 to 10 with an $\left(\mathrm{NH}_{4}\right)_{2} \mathrm{SO}_{4} / \mathrm{NH}_{4} \mathrm{OH}$ buffer solution to ensure that the distribution of the dissolved $\mathrm{Cr}$ redox species remains unchanged. This method calls for samples to be analyzed in the laboratory by ion chromatography with absorbance detection within 24 hours of collection. The ion chromatograph equipped with an absorbance detector and a small-volume sample cell is specialized instrumentation costing several tens of thousands of dollars. Older ion chromatographs cannot be retrofitted.

In contrast to the other two methods, the new cation-exchange method is not as timesensitive. Because only $\mathrm{Cr}(\mathrm{VI})$ remains in the sample after the cation-exchange separation and $\mathrm{Cr}$ (total) is determined in the analytical step, samples can be analyzed up to several weeks after collection, but care is needed to prevent contamination and ensure that a clean separation is achieved. Strong acid cation-exchange resin (AG50W-X8) will retain $\mathrm{Cr}$ (III), whereas $\mathrm{Cr}$ (VI) will pass into the effluent (Johnson, 1990). Sample pH is not critical, but must be between 2 and 11 so that all dissolved $\mathrm{Cr}(\mathrm{VI})$ is present as either the negatively-charged hydrogen chromate $\left(\mathrm{HCrO}_{4 \text { (aq) }}^{-}\right)$ or chromate $\left(\mathrm{CrO}_{4(\mathrm{aq})}^{2-}\right)$ ions and all dissolved $\mathrm{Cr}(\mathrm{III})$ is present as one or more of the positivelycharged $\mathrm{Cr}_{(\mathrm{aq})}^{3+}$, chromic monohydroxide $\left(\mathrm{CrOH}_{(\mathrm{aq})}^{2+}\right)$, or chromic dihydroxide $\left(\mathrm{Cr}(\mathrm{OH})_{2(\mathrm{aq})}^{+}\right)$ions. Although the selectivity of the AG50W-X8 resin for $\mathrm{Cr}_{(\mathrm{aq})}^{3+}$ is very high, the flow rate through the cartridge should be no greater than two drops per second so that $\mathrm{Cr}$ (III) species will be quantitatively retained.

The USEPA method 218.6 and the new cation-exchange method also differ in the availability of laboratory instrumentation. The ion chromatograph equipped with an absorbance detector and a small-volume sample cell is specialized instrumentation costing several tens of thousands of dollars. 
Older ion chromatographs cannot be retrofitted. The graphite furnace atomic absorption spectrometer (GFAAS), although similar in cost, is commonly available. Thus, typically no new instrument purchase is necessary to implement the analytical step of the new cation-exchange method.

\section{Limitations of the Cation-Exchange Method}

In the field, when processing water samples through the ion-exchange cartridges, the capacity of the resin must be considered. Samples of high ionic strength or high $\mathrm{Cr}$ (III) concentration may displace $\mathrm{Cr}_{(\mathrm{aq})}^{3+}$ from the cartridge and cause erroneously high results for $\mathrm{Cr}(\mathrm{VI})$. In such cases larger amounts of cation exchange resin must be used, and the volume of sample passed through the cartridge must be minimized. Cartridges are available in several sizes, and may be connected in series to achieve increased capacity. Any modifications made to the described conditions should be tested and verified before use.

Waters high in dissolved organic carbon may complex $\mathrm{Cr}$ (III) and prevent its retention by the cation-exchange resin (Icopini and Long, 2002). If waters to be tested are known or suspected to contain dissolved organic carbon at concentrations exceeding $5-10 \mathrm{mg} / \mathrm{L}$ this should be tested by adding known concentrations of $\mathrm{Cr}$ (III) standard to the test samples. Higher than expected apparent $\mathrm{Cr}(\mathrm{VI})$ concentrations are an indication that $\mathrm{Cr}(\mathrm{III})$ is not being retained by the resin.

\section{Accuracy of the Cation-Exchange Method: Standards and Spike Recoveries}

Demonstrating accuracy of the cation-exchange separation is challenging because no reference standards exist for redox species, and low concentrations of prepared standards may be difficult to maintain in their initial redox state. A series of standard solutions of single redox state was prepared in the laboratory, and $\mathrm{Cr}$ redox species were separated using the new method. The

results, presented in table 1, demonstrate that recoveries appear to have considerable variability for these solutions, and that the average recovery over the concentration range tested was about 91 percent. The recoveries were divided by the ratio of $\mathrm{Cr}$ found to $\mathrm{Cr}$ added for solution 1 , which was not cation-exchanged, to obtain the recoveries listed in column 5. Retention of Cr(III) was excellent, with an average $\mathrm{Cr}$ (III) retention of about 99.8 percent. 
Table 1. Recovery or retention from cation-exchanged $\mathrm{Cr}(\mathrm{III})$ and $\mathrm{Cr}(\mathrm{VI})$ standard solutions [Solution ID, solution identification; $\mu \mathrm{g} / \mathrm{L}$, micrograms per liter]

\begin{tabular}{clccc}
\hline & & \multicolumn{3}{c}{ Concentration $(\mu \mathrm{g} / \mathrm{L})^{\text {Recovery }^{1} \text { or }}$} \\
No. & Sotention \\
& \\
Relution ID & Cr(VI) Added & Cr Found & Percent \\
\hline 1 & $\mathrm{Cr}(\mathrm{VI})-10.0 \mu \mathrm{g} / \mathrm{L}^{3}$ & 10.0 & 9.2 & 100.0 \\
2 & $\mathrm{Cr}(\mathrm{VI})-0.1 \mu \mathrm{g} / \mathrm{L}$ & 0.10 & 0.12 & 126 \\
3 & $\mathrm{Cr}(\mathrm{VI})-0.2 \mu \mathrm{g} / \mathrm{L}$ & 0.20 & 0.15 & 80.9 \\
4 & $\mathrm{Cr}(\mathrm{VI})-0.5 \mu \mathrm{g} / \mathrm{L}$ & 0.50 & 0.34 & 74.0 \\
5 & $\mathrm{Cr}(\mathrm{VI})-1.0 \mu \mathrm{g} / \mathrm{L}$ & 1.0 & 0.85 & 92.5 \\
6 & $\mathrm{Cr}(\mathrm{VI})-2.5 \mu \mathrm{g} / \mathrm{L}$ & 2.5 & 2.1 & 89.1 \\
7 & $\mathrm{Cr}(\mathrm{VI})-5.0 \mu \mathrm{g} / \mathrm{L}$ & 5.0 & 3.9 & 85.5 \\
8 & $\mathrm{Cr}(\mathrm{VI})-10.0 \mu \mathrm{g} / \mathrm{L}$ & 10.0 & 8.4 & 90.9 \\
\hline 9 & $\mathrm{Cr}(\mathrm{III})-2.5 \mu \mathrm{g} / \mathrm{L}$ & 0.000 & $<0.05$ & 100.0 \\
10 & $\mathrm{Cr}(\mathrm{III})-5.0 \mu \mathrm{g} / \mathrm{L}$ & 0.000 & $<0.05$ & 100.0 \\
11 & $\mathrm{Cr}(\mathrm{III})-10.0 \mu \mathrm{g} / \mathrm{L}$ & 0.000 & 0.07 & 99.3 \\
\hline
\end{tabular}

${ }^{1}$ Recoveries, calculated for solutions 1-8, are adjusted for measured concentration of $\mathrm{Cr}$ standard (solution 1) by dividing recovery by the ratio of $\mathrm{Cr}$ found to $\mathrm{Cr}$ added.

${ }^{2}$ Retentions are calculated for solutions 9-11.

${ }^{3}$ Solution 1 was not cation-exchanged.

Four Cr-containing samples from the United Arab Emirates, North Carolina, Arizona, and the state of Washington were prepared for analysis by spiking them in the laboratory with 10, 20, or $30 \mu \mathrm{g} / \mathrm{L} \mathrm{Cr}$ (III). Each solution was then divided into two subsamples. One set of subsamples was separated by the cation-exchange method and analyzed by GFAAS. The second set of subsamples was preserved, and then analyzed by ion chromatography according to USEPA method 218.6. Results, shown in table 2 and figure 4, demonstrate that even for this diverse set of samples the two preservation and analysis methods have virtually equivalent capabilities to distinguish between $\mathrm{Cr}(\mathrm{VI})$ and $\mathrm{Cr}(\mathrm{III})$. The average recovery of $\mathrm{Cr}(\mathrm{VI})$ by USEPA method 218.6 was 98.3 percent, whereas the average recovery by the cation-exchange method analyzed by GFAAS was 98.0 percent. The anomalous result for sample UAE-30 from the cation-exchange method was not included in the recovery calculations. This sample is saline water with a specific conductance of more than 55,000 $\mu \mathrm{S} / \mathrm{cm}$ for which procedural modifications may be needed to achieve better cation-exchange separation of the $\mathrm{Cr}$ redox species. 
Table 2. Results of analyses of four Cr-containing samples, each spiked with three concentrations of Cr(III)

[ $\mu \mathrm{g} / \mathrm{L}$, micrograms per liter; USEPA 218.6, U.S. Environmental Protection Agency method 218.6; CE/GFAAS, cation-exchange method analyzed by graphite furnace atomic absorption spectrometry]

\begin{tabular}{|c|c|c|c|c|c|c|c|}
\hline \multirow[b]{3}{*}{ Sample Location } & \multirow{3}{*}{$\begin{array}{l}\text { Cr(III) } \\
\text { Added } \\
(\mu \mathrm{g} / \mathrm{L})\end{array}$} & \multirow{3}{*}{$\begin{array}{c}\mathrm{Cr}(\mathrm{III})+ \\
\mathrm{Cr}(\mathrm{VI}) \\
(\mu \mathrm{g} / \mathrm{L})\end{array}$} & \multirow[b]{3}{*}{ Expected } & \multirow{2}{*}{\multicolumn{2}{|c|}{$\begin{array}{l}\text { - - } \mathrm{Cr}(\mathrm{VI}), \mu \mathrm{g} / \mathrm{I} \\
\text { EPA } 218.6\end{array}$}} & \multirow{2}{*}{\multicolumn{2}{|c|}{$\mathrm{CE} / \mathrm{GFAAS}$}} \\
\hline & & & & & & & \\
\hline & & & & Found & $\begin{array}{l}\text { Recovery } \\
\text { (Percent) } \\
\end{array}$ & Found & $\begin{array}{l}\text { Recovery } \\
\text { (Percent) }\end{array}$ \\
\hline $\begin{array}{l}\text { United Arab } \\
\text { Emirates }\end{array}$ & 10 & 19.2 & 9.2 & 10.1 & 110 & 9.5 & 104 \\
\hline $\begin{array}{l}\text { United Arab } \\
\text { Emirates }\end{array}$ & 20 & 29.2 & 9.2 & 9.9 & 107 & 9.9 & 108 \\
\hline $\begin{array}{l}\text { United Arab } \\
\text { Emirates }\end{array}$ & 30 & 39.2 & 9.2 & 9.4 & 102 & ${ }^{1} 3.7$ & 40.4 \\
\hline North Carolina & 10 & 14.8 & 4.8 & 4.6 & 96.3 & 4.9 & 101 \\
\hline North Carolina & 20 & 24.8 & 4.8 & 4.3 & 90.1 & 4.7 & 97.8 \\
\hline North Carolina & 30 & 34.8 & 4.8 & 4.4 & 92.7 & 4.8 & 99.0 \\
\hline Arizona & 10 & 18.1 & 8.1 & 8.3 & 103 & 7.8 & 96.6 \\
\hline Arizona & 20 & 28.1 & 8.1 & 7.7 & 94.8 & 8.1 & 99.8 \\
\hline Arizona & 30 & 38.1 & 8.1 & 7.7 & 95.2 & 7.7 & 94.9 \\
\hline Washington & 10 & 19.7 & 9.7 & 9.3 & 96.1 & 8.6 & 89.0 \\
\hline Washington & 20 & 29.7 & 9.7 & 9.3 & 96.5 & 9.1 & 93.9 \\
\hline Washington & 30 & 39.7 & 9.7 & 9.3 & 96.0 & 9.1 & 94.4 \\
\hline
\end{tabular}

${ }^{1}$ This result was not included in average recovery calculations.

\section{Comparison of Cation-Exchange Method Results with Results from Alternative Methods}

The Hach Company (1992) DPC direct colorimetric method was modified by using a diodearray spectrophotometer and a 5-cm measuring cell to determine $\mathrm{Cr}(\mathrm{VI})$ in a mobile laboratory truck at a Mojave Desert field site in Califormia. This resulted in improvement of the detection limit from about $10 \mu \mathrm{g} / \mathrm{L}$ to about $0.3 \mu \mathrm{g} / \mathrm{L}$. In June 2002, more than 100 ground water samples from the Mojave Desert field site were analyzed for Cr(VI) using the modified Hach Company DPC direct colorimetric method and the new cation-exchange method with analysis by GFAAS. The results, shown in figure 3, demonstrate excellent comparability between the two methods indicating that, to the extent the Hach DPC method is accurate, the new cation-exchange method is at least as accurate and, owing to its 10-fold lower detection limit, is more sensitive. 


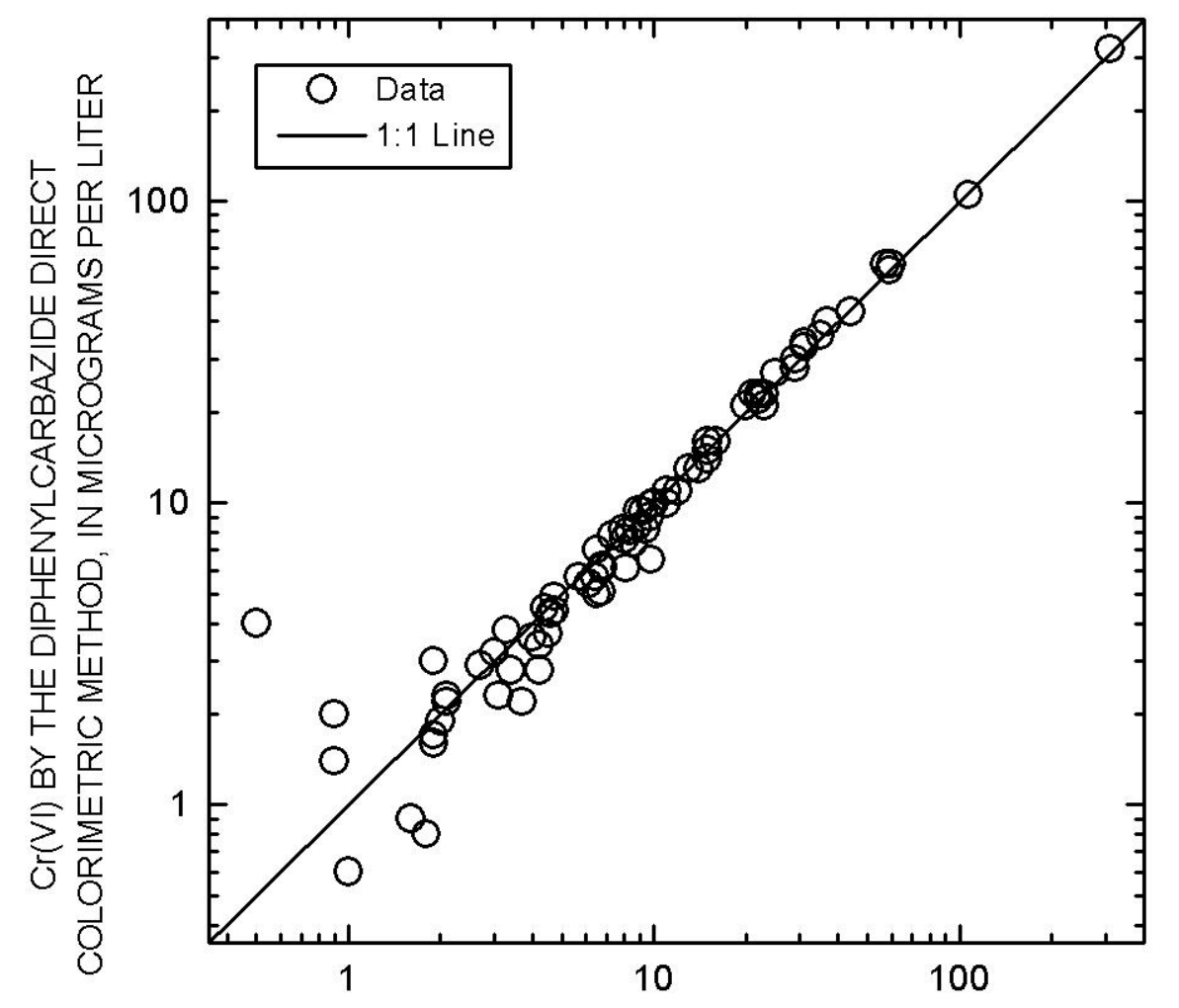

Cr(VI) BY THE CATION-EXCHANGE METHOD WITH ANALYSIS BY GRAPHITE FURNACE ATOMIC ABSORPTION SPECTROMETRY, IN MICROGRAMS PER LITER

Figure 3. $\mathrm{Cr}(\mathrm{VI})$ determinations by the modified Hach DPC direct colorimetric method and by the cation-exchange method.

Many samples from diverse sources were analyzed using the cation-exchange method and USEPA method 218.6 (Arar and others, 1991). The results (fig. 4, table 3) illustrate that, for these samples and over the $\mathrm{Cr}(\mathrm{VI})$ range covered, the new cation-exchange method produces $\mathrm{Cr}(\mathrm{VI})$ concentrations essentially identical to USEPA method 218.6. The large percentage differences in table 3 are for samples having low Cr concentrations; thus, actual differences in the $\mathrm{Cr}(\mathrm{VI})$ concentrations are small. 


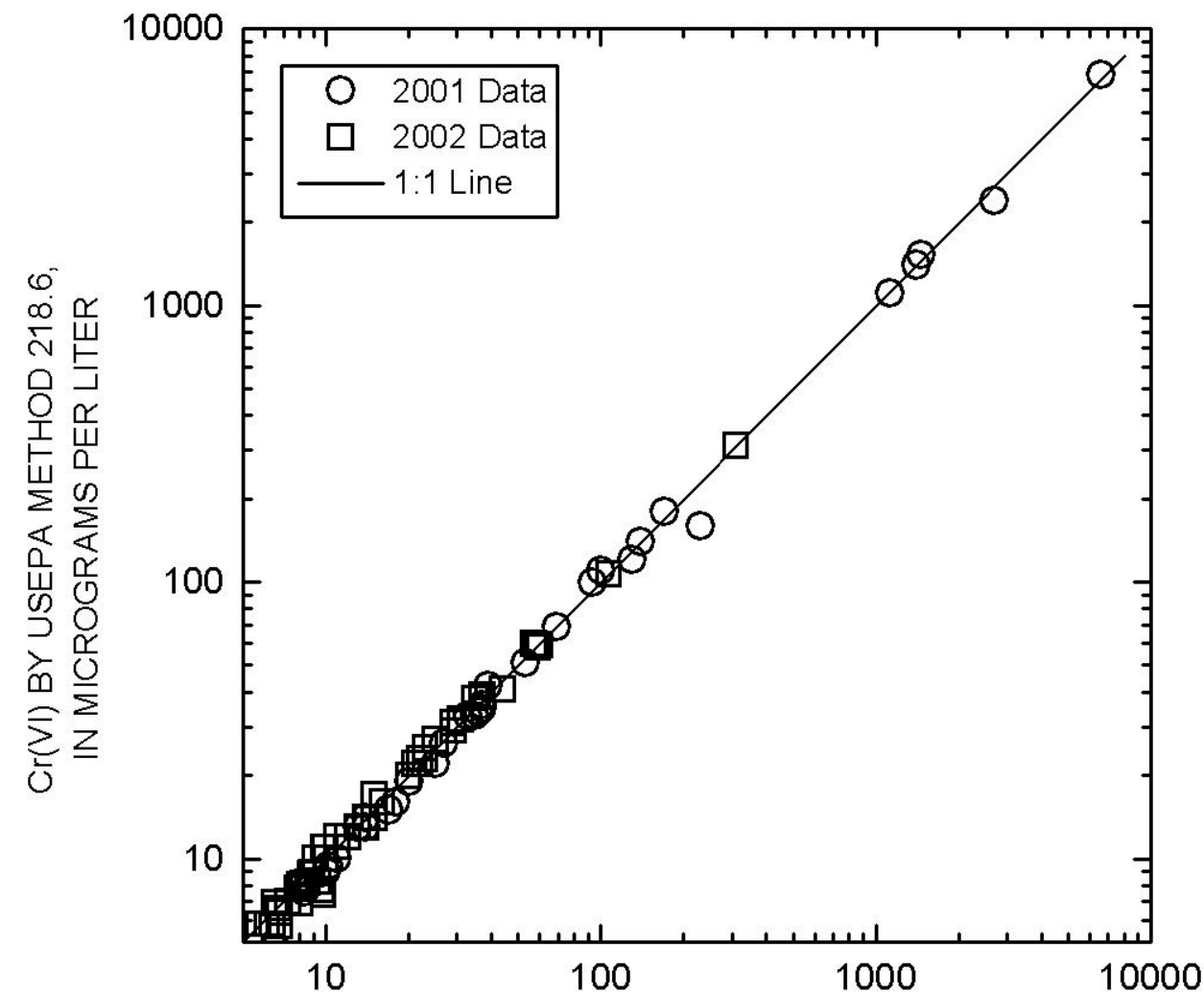

Cr(VI) BY THE CATION-EXCHANGE METHOD WITH ANALYSIS BY GRAPHITE FURNACE ATOMIC ABSORPTION SPECTROMETRY, IN MICROGRAMS PER LITER

Figure 4. Cr(VI) determinations by USEPA method 218.6 and by the cation-exchange method. 
Table 3. Comparative $\mathrm{Cr}(\mathrm{VI})$ determinations in waters from around the world.

$[\mu \mathrm{g} / \mathrm{L}$, micrograms per liter; Cation-exchange, cation-exchange method with analysis by graphite furnace atomic absorption spectrometry; USEPA 218.6, U.S. Environmental Protection Agency method 218.6; ---, not calculated]

\begin{tabular}{|c|c|c|c|}
\hline \multirow{2}{*}{$\begin{array}{l}\text { Sample } \\
\text { Description }\end{array}$} & \multicolumn{2}{|c|}{$\mathrm{Cr}(\mathrm{VI})(\mu \mathrm{g} / \mathrm{L})$} & \multirow{2}{*}{$\begin{array}{c}\text { Difference } \\
\text { (percent) }\end{array}$} \\
\hline & Cation-exchange & USEPA 218.6 & \\
\hline United Arab Emirates well LWS-1 & 100 & 110 & -9.5 \\
\hline United Arab Emirates well LWS-15 & 170 & 180 & -5.7 \\
\hline United Arab Emirates well LWS-18 & 140 & 140 & 0.0 \\
\hline United Arab Emirates well QWS-37 & 230 & 160 & 36 \\
\hline United Arab Emirates well LWS-2 & 130 & 120 & 8.0 \\
\hline United Arab Emirates well LWS-16 & 140 & 140 & 0.0 \\
\hline Maqarin, Jordan ground water & 6600 & 6800 & -3.0 \\
\hline Elizabeth City, North Carolina ground water & 2700 & 2400 & 11.8 \\
\hline Ranegras, Arizona well RAN-10 & 69 & 69 & 0.0 \\
\hline Hughes Missile Systems, Arizona well E-12 & 39 & 42 & -7.4 \\
\hline Hanford, Washington well 100-K & 93 & 100 & -7.3 \\
\hline Pantex, Texas well DM-20 & 1400 & 1400 & 0.0 \\
\hline El Mirage, California well 25M2 & 53 & 51 & 4.1 \\
\hline Hinkley, California well MW15 & 1120 & 1110 & 1.4 \\
\hline Hinkley, California well PMW6 & 1470 & 1520 & -3.5 \\
\hline 29 Palms MCAGCC, California well 32D4 & 10 & 9.4 & 8.2 \\
\hline 29 Palms MCAGCC, California well 32D6 & 11 & 10 & 8.2 \\
\hline 29 Palms MCAGCC, California well CW2-1 & 0.5 & 0.1 & 117 \\
\hline 29 Palms MCAGCC, California well CW2-2 & 10 & 9.0 & 10.2 \\
\hline 29 Palms MCAGCC, California well CW2-3 & 14 & 13 & 7.8 \\
\hline 29 Palms MCAGCC, California well CW3-1 & 8.4 & 7.6 & 10.2 \\
\hline 29 Palms MCAGCC, California well CW3-2 & 13 & 13 & -1.8 \\
\hline 29 Palms MCAGCC, California well CW3-3 & 14 & 14 & 0.0 \\
\hline 29 Palms MCAGCC, California well SSR-1 & 25 & 22 & 11.4 \\
\hline 29 Palms MCAGCC, California well SSR-3 & 18 & 16 & 13.3 \\
\hline 29 Palms MCAGCC, California well SSR-4 & 27 & 26 & 4.3 \\
\hline 29 Palms MCAGCC, California well SW-5 & 20 & 19 & 8.4 \\
\hline 29 Palms MCAGCC, California well SW-9A & 17 & 15 & 15.5 \\
\hline 29 Palms MCAGCC, California WW POND & 2.8 & 0.5 & 142 \\
\hline Joshua Basin Water District well 16-360' & 1.9 & 0.4 & 135 \\
\hline Joshua Basin Water District well 16-410' & 2.0 & $<0.1$ & --- \\
\hline Joshua Basin Water District well 16-590' & 1.7 & $<0.1$ & --- \\
\hline Joshua Basin Water District well 16-615' & 36 & 34 & 6.0 \\
\hline Joshua Basin Water District well 16-680' & 37 & 36 & 3.4 \\
\hline Joshua Basin Water District well 16-750' & 37 & 35 & 6.3 \\
\hline Joshua Basin Water District well 16-820' & 35 & 33 & 8.0 \\
\hline Joshua Basin Water District well 16-bulk sample & 33 & 33 & -0.2 \\
\hline Joshua Basin Water District blank & 0.3 & $<0.1$ & --- \\
\hline
\end{tabular}




\section{pH Dependence of the Cation-Exchange Separation}

A set of laboratory standards was prepared containing $20 \mu \mathrm{g} / \mathrm{L}$ each of $\mathrm{Cr}(\mathrm{III})$ and $\mathrm{Cr}(\mathrm{VI})$. Each solution was subsampled using the new cation-exchange method and preserved for analysis by GFAAS, then preserved and analyzed by USEPA method 218.6. The results, shown in figure 5, demonstrate that, for these simple standard solutions, the cation-exchange separation is effective over the range $\mathrm{pH} 2$ to $\mathrm{pH} 11$.

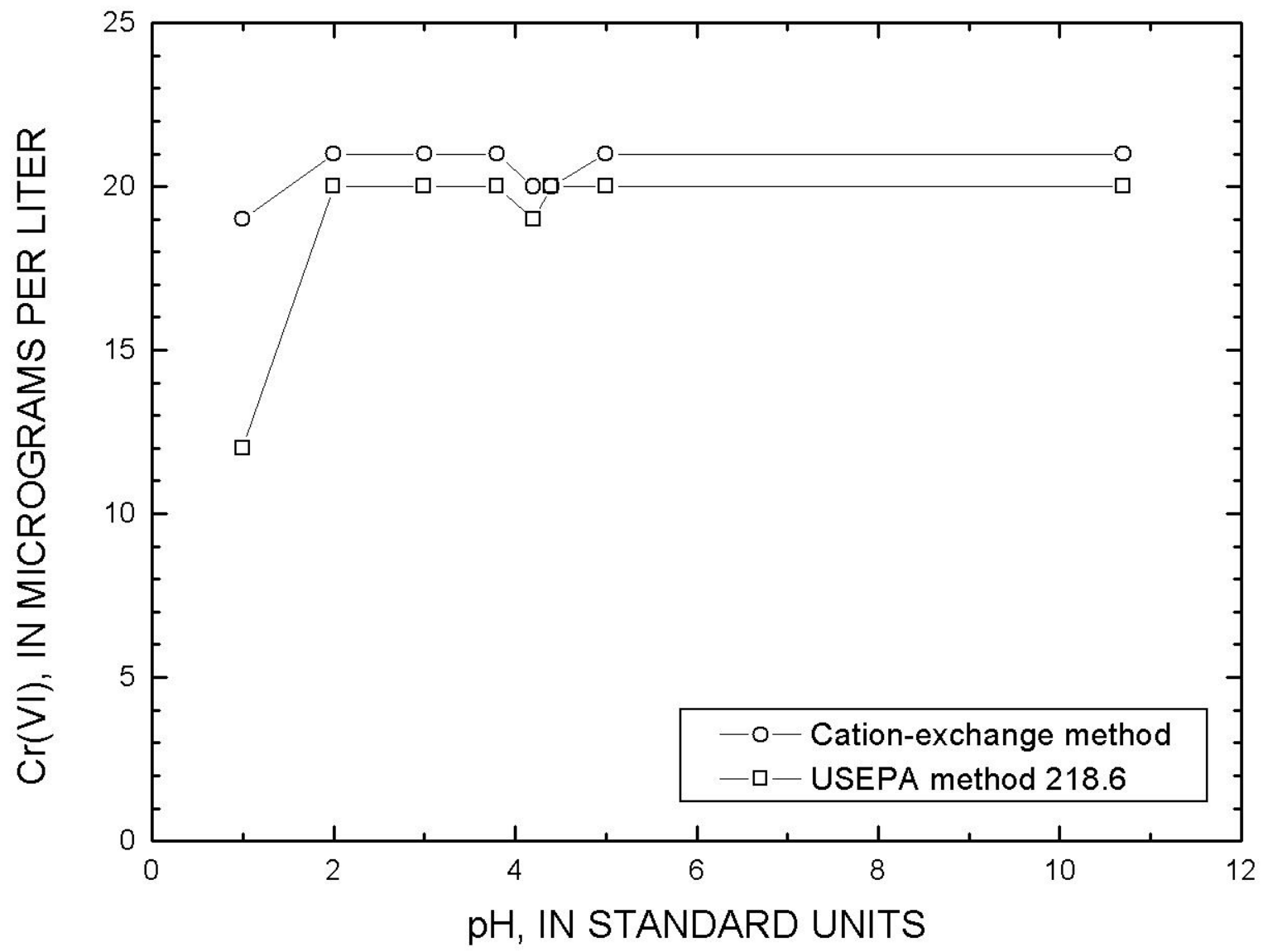

Figure 5. $\mathrm{pH}$ dependence of $\mathrm{Cr}(\mathrm{VI})$ separation from synthetic solutions containing 20 micrograms per liter each of $\mathrm{Cr}(\mathrm{III})$ and $\mathrm{Cr}(\mathrm{VI})$

\section{Effects of Potential Interfering Species on the Cation-Exchange and USEPA Methods}

The effects of large concentrations of $\mathrm{Cr}(\mathrm{III})$, three major cations ( $\mathrm{Na}, \mathrm{Ca}$, and $\mathrm{Mg}$ ), one alkaline earth cation with a relatively high selectivity (Ba), $\mathrm{Fe}(\mathrm{II})$, and $\mathrm{Fe}(\mathrm{III})$ were tested by spiking solutions containing 20 $\mu \mathrm{g} / \mathrm{L}$ each of $\mathrm{Cr}(\mathrm{III})$ and $\mathrm{Cr}(\mathrm{VI})$. The results, shown in figures 6-9, illustrate that (1) $\mathrm{Cr}(\mathrm{III})$ concentrations at least 50 times that of the $\mathrm{Cr}(\mathrm{VI})$ concentration can be separated from simple solutions containing $\mathrm{Cr}(\mathrm{III})$ and 
$\mathrm{Cr}(\mathrm{VI})$ (fig. 6); (2) $\mathrm{Na}, \mathrm{Ca}$, and $\mathrm{Mg}$ at concentrations as large as $1000 \mathrm{mg} / \mathrm{L}$ and $\mathrm{Ba}$ at concentrations as large as $100 \mathrm{mg} / \mathrm{L}$ have a negligible effect on the separation of $\mathrm{Cr}(\mathrm{III})$ and $\mathrm{Cr}(\mathrm{VI})$ (figs. 7 and 8); and (3) concentrations of $\mathrm{Fe}(\mathrm{II})$ or $\mathrm{Fe}(\mathrm{III})$ greater than 50 times those of $\mathrm{Cr}(\mathrm{VI})$ dramatically affect the recovery of Cr(VI) (fig. 9).

The $\mathrm{Cr}$ (III) stock solution used was not specified as containing only $\mathrm{Cr}$ (III). This solution contained approximately $0.38 \mu \mathrm{g} / \mathrm{L} \mathrm{Cr}(\mathrm{VI})$ per $1 \mathrm{mg} / \mathrm{L} \mathrm{Cr}(\mathrm{III})$, or about 0.038 percent $\mathrm{Cr}(\mathrm{VI})$. The results, corrected for the $\mathrm{Cr}(\mathrm{VI})$ content of the stock solution and shown in fig. 6, indicate potential for $\mathrm{Cr}(\mathrm{III})$ to pass through the cation-exchange cartridge when the $\mathrm{Cr}(\mathrm{III}) / \mathrm{Cr}(\mathrm{VI})$ concentration ratio is 500 . While the source of this problem is not known, it is most likely a function of liquid flow within the cartridges, whereby there is insufficient contact of the solution with the cation-exchange resin. The maximum concentration of $\mathrm{Cr}$ (III) passing through the cartridge is about $8 \mu \mathrm{g} / \mathrm{L}$ in the presence of $10,000 \mu \mathrm{g} / \mathrm{L} \mathrm{Cr}(\mathrm{III})$. This constitutes at worst better than 99.9 percent retention of $\mathrm{Cr}(\mathrm{III})$, and is consistent with the results of the experiment described earlier in this report (table 1) using $\mathrm{Cr}$ (III) concentrations three orders of magnitude smaller. For solutions with $\mathrm{Cr}(\mathrm{VI})$ concentrations less than $10 \mu \mathrm{g} / \mathrm{L}$ and $\mathrm{Cr}(\mathrm{III}) / \mathrm{Cr}(\mathrm{VI})$ concentration ratios greater than 500, the error could approach 100 percent. If a solution having these $\mathrm{Cr}(\mathrm{III})$ and $\mathrm{Cr}(\mathrm{VI})$ concentrations is identified, multiple replicates should be separated using larger cation-exchange cartridges.

In the case of $\mathrm{Na}, \mathrm{Ca}, \mathrm{Mg}$ (fig. 7), and $\mathrm{Ba}$ (fig. 8), little effect on recoveries is seen using either the new cation-exchange method or USEPA method 218.6. These results demonstrate that the new method and USEPA method 218.6 are equivalent in their ability to accurately determine $\mathrm{Cr}(\mathrm{VI})$ in the presence of large excesses of these major cations.

In the case of $\mathrm{Fe}(\mathrm{II})$, USEPA method 218.6 appears to provide accurate recoveries at an excess of at least 500 -fold [10 mg/L Fe(II) in solution with $20 \mu \mathrm{g} / \mathrm{L}$ each of $\mathrm{Cr}(\mathrm{III})$ and $\mathrm{Cr}(\mathrm{VI})$ ], whereas the new cationexchange method yields less than 50 percent recovery at these concentrations. The Fe(II) most likely reduced $\mathrm{Cr}(\mathrm{VI})$ to $\mathrm{Cr}(\mathrm{III})$ before the cation-exchange separation could be completed. USEPA method 218.6 does not produce accurate recoveries at a 5-fold excess concentration of $\mathrm{Fe}(\mathrm{III})$ whereas the new cation-exchange method produces accurate recoveries at up to a 500 -fold Fe(III) concentration excess. Because of the necessity in USEPA method 218.6 to adjust the sample $\mathrm{pH}$ to values above $9, \mathrm{Fe}$ (III) is most likely hydrolyzing and coprecipitating with or adsorbing Cr. At $100 \mathrm{mg} / \mathrm{L}$ in the case of USEPA method 218.6, both Fe(II) and $\mathrm{Fe}(\mathrm{III})$ hydrolyze during $\mathrm{pH}$ adjustment, removing virtually all $\mathrm{Cr}$ from the solutions. The new cationexchange method also performs less effectively at $\mathrm{Fe}(\mathrm{II})$ and $\mathrm{Fe}(\mathrm{III})$ concentrations of $100 \mathrm{mg} / \mathrm{L}$. 


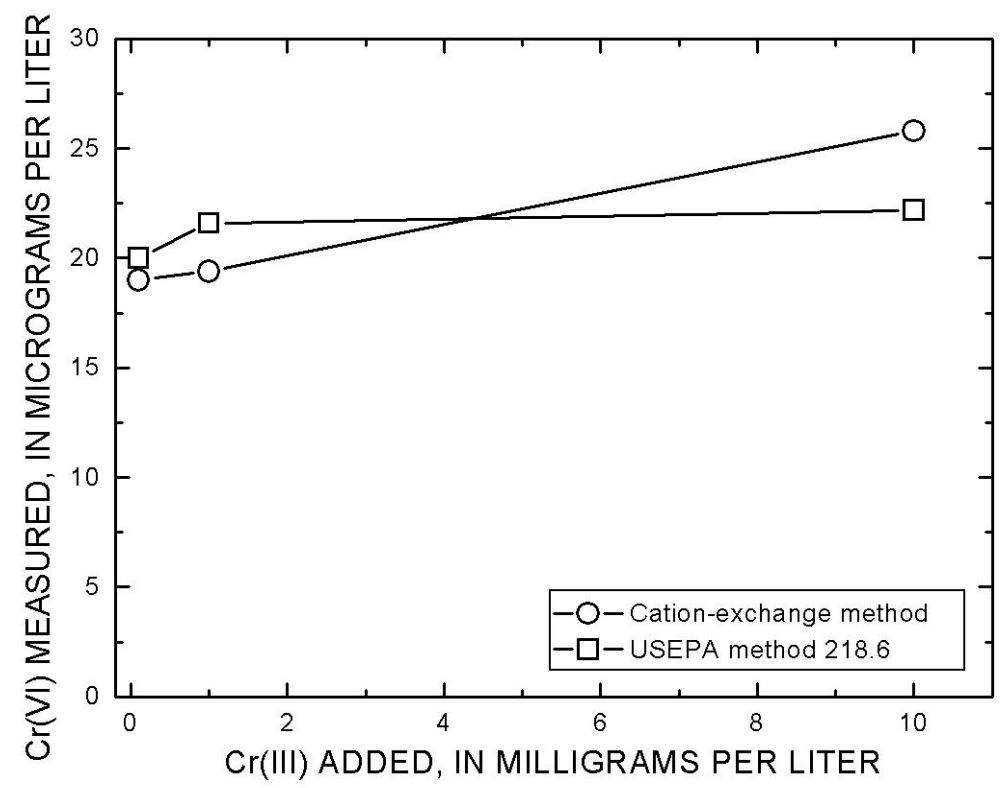

Figure 6. Recovery of 20 micrograms per liter $\mathrm{Cr}(\mathrm{VI})$ from solutions containing 0.1 to 10 milligrams per liter $\mathrm{Cr}(\mathrm{III})$.

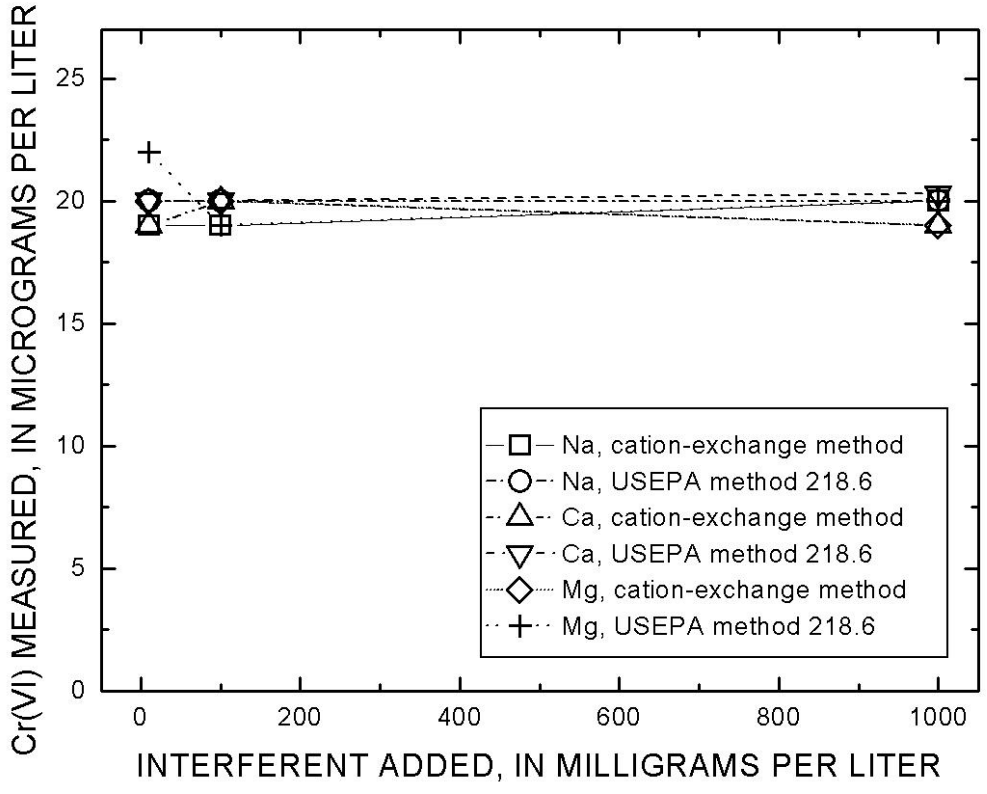

Figure 7. Recovery of 20 micrograms per liter $\mathrm{Cr}(\mathrm{VI})$ from solutions containing 20 micrograms per liter $\mathrm{Cr}$ (III) and 10 to 1000 milligrams per liter $\mathrm{Na}, \mathrm{Ca}$, or $\mathrm{Mg}$. 


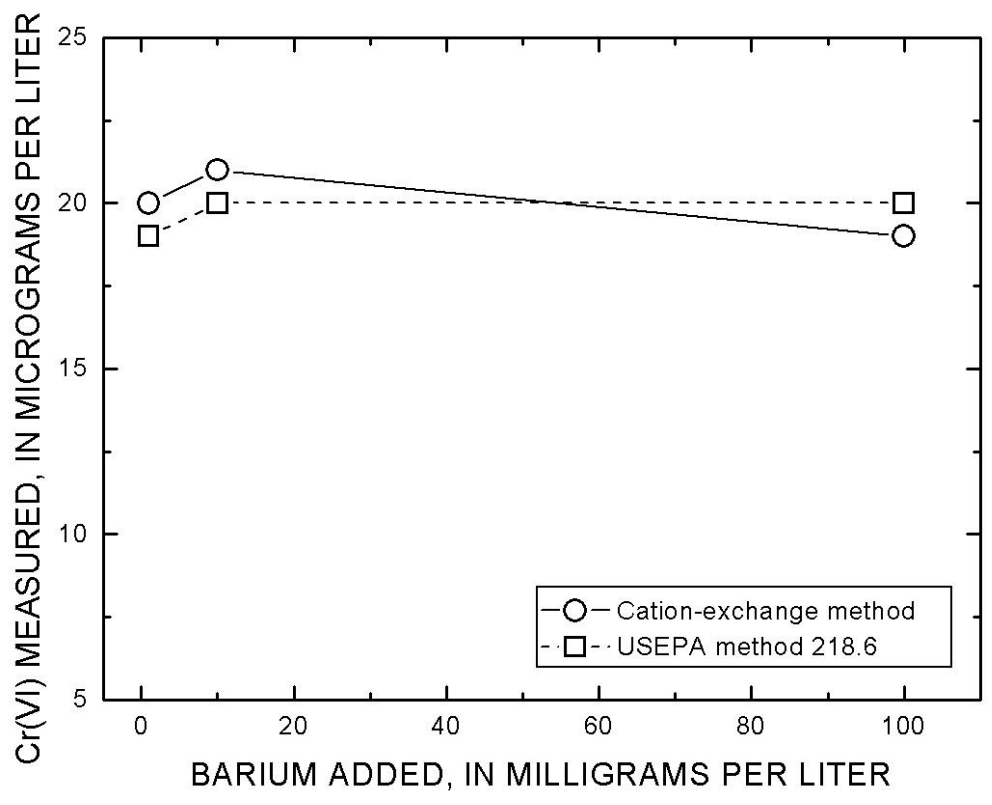

Figure 8. Recovery of 20 micrograms per liter $\mathrm{Cr}(\mathrm{VI})$ from solutions containing 20 micrograms per liter $\mathrm{Cr}(\mathrm{III})$ and 1 to 100 milligrams per liter Ba.

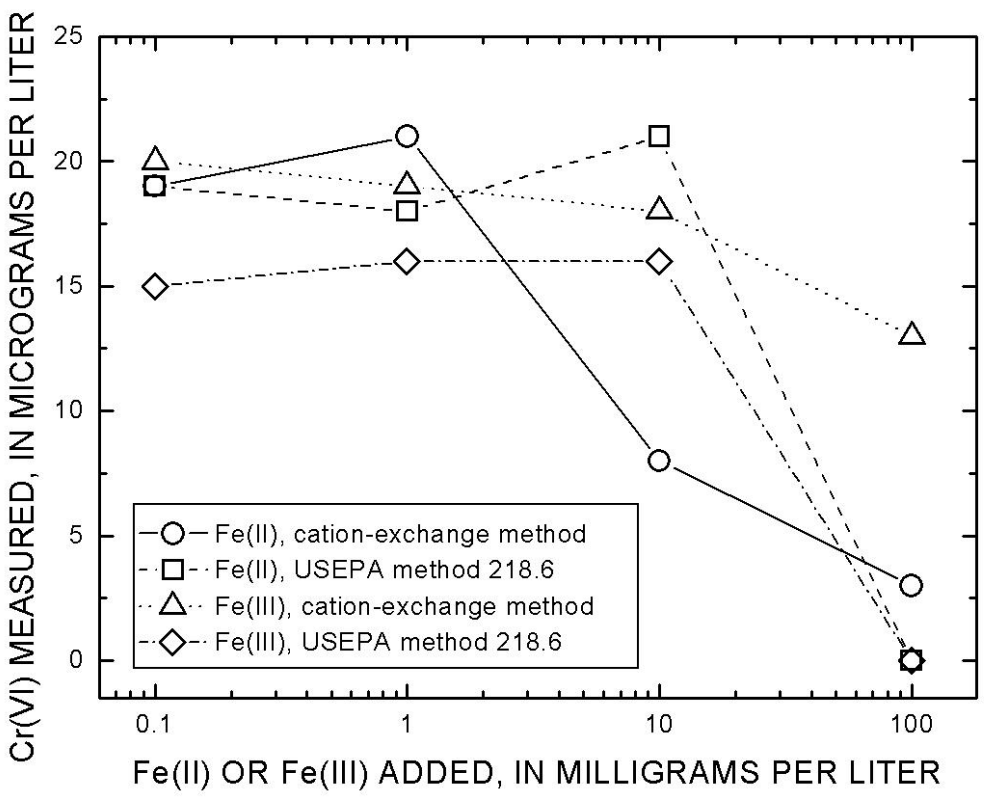

Figure 9. Recovery of 20 micrograms per liter $\mathrm{Cr}(\mathrm{VI})$ from solutions containing 20 micrograms per liter $\mathrm{Cr}(\mathrm{III})$ and 0.1 to 100 milligrams per liter $\mathrm{Fe}(\mathrm{II})$ or $\mathrm{Fe}(\mathrm{III})$. 


\section{SUMMARY}

A new cation-exchange method for field speciation of $\mathrm{Cr}(\mathrm{VI})$ for later determination of its concentration has been developed. The method is simple, rapid, portable, and accurate, and makes use of readily available, inexpensive materials. Determination of $\mathrm{Cr}(\mathrm{VI})$ concentrations can be done later in the laboratory using any elemental analysis instrument that is sufficiently sensitive to measure the $\mathrm{Cr}$ (VI) concentrations of interest. Chromium(VI) can be separated from $\mathrm{Cr}$ (III) at $\mathrm{Cr}(\mathrm{VI}) / \mathrm{Cr}$ (III) concentration ratios as low as 0.001 and between $\mathrm{pH} 2$ and $\mathrm{pH} 11$. The new method, using analysis by graphite furnace atomic absorption spectrometry, has demonstrated excellent comparability with two commonly used methods, the Hach Company direct colorimetric method and USEPA method 218.6 using the ion chromatographic/colorimetric analytical technique. The new method is superior to the Hach direct colorimetric method owing to its relative simplicity and sensitivity, and to USEPA method 218.6 because significantly increased sample holding times after collection are allowed. The determination is superior to USEPA method 218.6 in the presence of $\mathrm{Fe}(\mathrm{II})$ concentrations up to $1 \mathrm{mg} / \mathrm{L}$ and $\mathrm{Fe}(\mathrm{III})$ concentrations up to $10 \mathrm{mg} / \mathrm{L}$. 


\section{REFERENCES}

Arar, E.J., Long, S.E., and Pfaff, J.D., 1991, Determination of dissolved hexavalent chromium in drinking water, groundwater and industrial wastewater effluents by ion chromatography: U.S. Environmental Protection Agency, Method 218.6, revision 3.0.

Arar, E.J., and Pfaff, J.D. 1991, Determination of dissolved hexavalent chromium in industrial wastewater effluents by ion chromatography and post-column derivatization with diphenylcarbazide: Journal of Chromatography, v. 546, p. 335-340.

Bajt, S., Clark, S.B., Sutton, S.R., Rivers, M.L., and Smith, J.V., 1993, Synchrotron x-ray microprobe determination of chromate content using $\mathrm{x}$-ray absorption near-edge structure: Analytical Chemistry, v. 65, p. 1800-1804.

Daugherty, M. L., 1992, Toxicity Summary for Chromium: Oak Ridge, Oak Ridge National Laboratory Chemical Hazard Evaluation and Communication Group, no. 26.

Escobar, R., Lin, Q., Guiraum, A., and de la Rosa, F.F., 1995, Determination of trivalent and hexavalent chromium in waste water by flow injection chemiluminescence analysis: International Journal of Environmental Analytical Chemistry, v. 61, p. 169-175.

Frenzel, W., 1998, Highly sensitive semi-quantitative field test for the determination of chromium (VI) in aqueous samples: Fresenius Journal of Analytical Chemistry, v. 361, p. 774-779.

Hach Company, 1992, Chromium, hexavalent, for water and wastewater, Method 8023, In DR/2000 Spectrophotometer Procedures Manual, $7^{\text {th }}$ Ed.: Loveland, CO, Hach Co., p. 113-117.

Icopini, G.A., and Long, D.T., 2002, Speciation of aqueous chromium by use of solid phase extractions in the field: Environmental Science and Technology, v. 36, p. 2994-2999.

Johnson, C.A., 1990, Rapid ion-exchange technique for the separation and preconcentration of chromium(VI) and chromium(III) in fresh waters: Analytica Chimica Acta, v. 238, p. 273278.

Manzoori, J.L., Sorouraddin, M.H., and Shemiran, F., 1996, Preconcentration and spectrophotometric determination of chromium (VI) and total chromium in drinking water by the sorption of chromium diphenylcarbazide with surfactant coated alumina: Analytical Letters, v. 29, p. 2007-2014. 